\title{
Parametric Study on Waverider Configurations at Low-supersonic Speed for Low-boom Supersonic Transport*
}

\author{
Potsawat BOONJAIPETCH, ${ }^{1), 2) \dagger}$ Koji SHIMOYAMA, ${ }^{2)}$ and Shigeru OBAYASHI ${ }^{2)}$ \\ ${ }^{1)}$ Institute of Fluid Science, Tohoku University, Sendai, Miyagi 980-8577, Japan \\ ${ }^{2)}$ Department of Aerospace Engineering, Tohoku University, Sendai, Miyagi 980-8579, Japan
}

\begin{abstract}
Research on supersonic transport seeks to overcome two main challenges, to mitigate sonic boom and improve aerodynamic performance, in order to become environmentally viable and economically practicable. To achieve these goals, this research proposes a waverider configuration to solve the challenge of designing commercial supersonic aircraft. The waverider is famous for providing a higher lift-to-drag ratio than that provided by other conventional designs for supersonic and hypersonic flights. The study of three types of supersonic waveriders, cone-derived, power-law, and osculatingcone waverider, is introduced for low-supersonic designs. The flight condition includes a speed of Mach 1.5 at an altitude of $18,000 \mathrm{~m}$. An unstructured grid with an inviscid Euler equation solver is used to calculate the flow field of the vehicle. The ground noise post-processing uses an augmented Burgers equation solver to assist in far-field signature evaluation. The result of a cone-derived waverider provided significant volume with low overpressure, while the power-law waverider showed the advantages of aerodynamic performance and ample design space. The osculating-cone waverider obtained the merits from both the cone-derived and power-law waveriders. The waverider is expected to have a quality that satisfies the design objectives of supersonic aircraft: high aerodynamic performance and sonic boom mitigation.
\end{abstract}

Key Words: Aerodynamics, Supersonic Transport, Waverider, Low Boom

\section{Nomenclature}

$C_{L}:$ lift coefficient

$C_{D}$ : drag coefficient

$H$ : vehicle height

$L$ : vehicle length

$R_{0}$ : radial distance projected to center base plane

$Y_{G}$ : a point on base plane lower surface

$Y_{F}$ : a point on base plane upper surface

$Y_{u}: y$-coordinate of the upper-surface curve

$Y_{p}: y$-coordinate of the lower-surface curve

$z_{u}: z$-coordinate of the upper-surface curve

$z_{L}: z$-coordinate of the base plane

$n$ : power-law component

$x, y, z:$ cartesian coordinates

$\beta$ : leading-edge shock angle

$\delta$ : half-cone angle

$\phi$ : dihedral angle

$\lambda$ : local swept angle

$\theta$ : wedge angle

$\delta_{1}$ : local dihedral angle on the lower surface

$\delta_{2}$ : local dihedral angle on the upper surface

\section{Introduction}

Supersonic aircraft operation provides significant speed travel advantages over subsonic flight operations, especially at greater distances, as the value of rapid travel increases over

(C) 2021 The Japan Society for Aeronautical and Space Sciences

*Received 10 September 2020; final revision received 14 April 2021; accepted for publication 26 May 2021.

†Corresponding author, boonjaipetch.potsawat.s4@dc.tohoku.ac.jp the distance. Current supersonic aircraft have an operating range of 4,000 to 6,000 nautical miles, ${ }^{1,2)}$ compared to a subsonic airliner that operates at 8,000 nautical miles. Improvement is required if supersonic aircrafts are to compete.

Since the 1960s, several famous commercial supersonic aircraft have been released and used in civil aviation. However, many have been retired due to high costs and sonic boom regulation. ${ }^{3)}$ An effort to bring them back has guided the proposal of different solutions and methods ${ }^{4-6)}$ for mitigating these issues. From the viewpoint of aerodynamic design, the most critical issues are sonic boom and fuel consumption, which have consequences in noise policy and the cost per seat. It is an important goal to develop an airframe that can mitigate the sonic boom and improve the lift-to-drag ratio $(L / D)$ for better aerodynamic performance. The benefit of a high $L / D$ is expressed using the Breguet range equation in a cruise range. An aircraft with a higher $L / D$ can decrease fuel consumption a flight of equal distance.

This paper focuses on a low-boom supersonic aircraft configuration that can achieve high aerodynamic performance, and the waverider is an interesting candidate. The concept of a waverider was first introduced and developed around 1950s. ${ }^{7,8)}$ The trend of aircraft design has developed towards higher speeds, and as such, the aerospace engineering research field has continuously pushed the limits of propulsion technology, such as when the turbojet advanced and replaced to piston engine. Furthermore, researchers have worked to increase the limit of supersonic travel (Mach 1-3) to hypersonic travel (Mach 5-25). Therefore, they have developed one of the most efficient approaches to utilize the high-speed environment-the waverider. In short, a waverider is any ve- 
hicle that uses its own generated shock wave to improve its overall performance. If the aircraft is designed correctly, it can ride this wave to produce more significant lift, less drag, and greater range, leading to overall improved performance. The reason waveriders are remarkably effective at higher Mach numbers is that the generated shock wave remains close to the bottom surface of the aircraft. This phenomenon is called "compression lift," and is the primary benefit of the waverider concept.

A waverider has the potential to utilize the shock riding concept for developing commercial supersonic aircraft. The mission requirement for developing supersonic transport speed for overland flight is still considered to be lowsupersonic (Mach 1.2-1.8). At the same time, the sonic boom generated by the waverider has never been discussed and revealed, particularly at low-supersonic speeds. In this study, three waverider design methods are introduced to study performance at a low-supersonic speed. The initial condition is set for supersonic flight. The aim is to observe the trend of geometric parameters for aerodynamic performance and sonic boom strength. This paper further discusses the utilization of the shock-capturing area of the waverider at low supersonic speeds and its improvements in terms of aerodynamic performance and overpressure.

\section{Supersonic Waverider}

The original idea of waveriders was described in 1951, when Terence Nonweiler proposed the general idea of a classic waverider. ${ }^{7,8)}$ The configuration of the waverider aims to improve the aerodynamic performance of a vehicle that is traveling faster than the speed of sound. By utilizing the shock wave underneath the aircraft, the waverider geometry forms a shock wave that is attached or nearly attached to the vehicle's leading-edge, thereby creating compression lift on the lower surface. A waverider comprises three surfaces, as illustrated in Fig. 1. The upper surface is the freestream surface, below is the compression surface, and the structure that intersects the two surfaces is called the base plane. Three

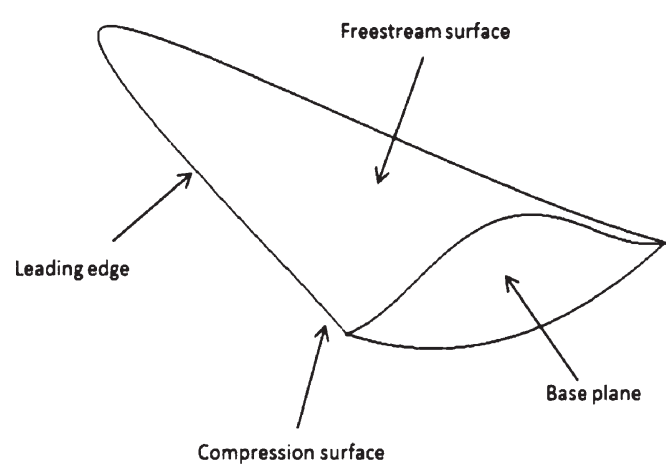

Fig. 1. A generic waverider. It is composed of three surfaces: freestream surface, compression surface, and base plane. The leading-edge is the intersection curve between the freestream surface and compression surface. The surfaces are designed corresponding to the shock angle of an object (e.g., cone and wedge) to utilize the high-pressure area from the shock wave. types of waverider configurations are now being studied under supersonic conditions to observe aerodynamics and overpressure at low supersonic speeds.

\subsection{Cone-derived waverider}

A waverider was tailored with a cone shape and parabolic trailing-edge. Several researchers have developed and investigated both cones and perturbed cones to achieve the best solution for the attached shock surface. ${ }^{9,10)}$ The shock wave around the vehicle is estimated using the Taylor-Maccoll relation, which is an approximated relation valid for a conical flow with a small cone half-angle. A cone-derived waverider was generated using the following steps: First, a flow field was generated by assuming supersonic flow passes through a right circular cone at a particular freestream Mach $\left(M_{\infty}\right)$ number and shock angle $(\beta)$, as shown in Fig. 2. The specific heat ratio $(\gamma)$ in this scenario was set to 1.4. The TaylorMaccoll relation given by Eq. (1) was solved to obtain the half-cone angle $(\delta)$.

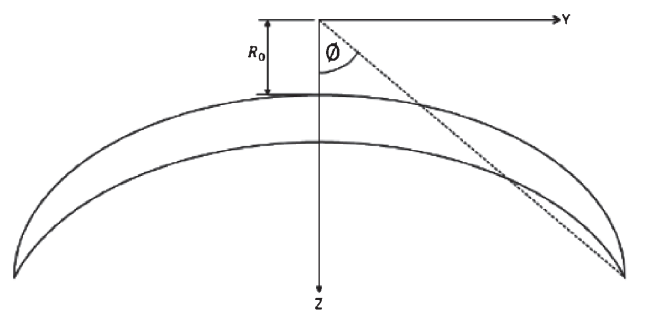

(a) Back view of waverider in YZ-plane

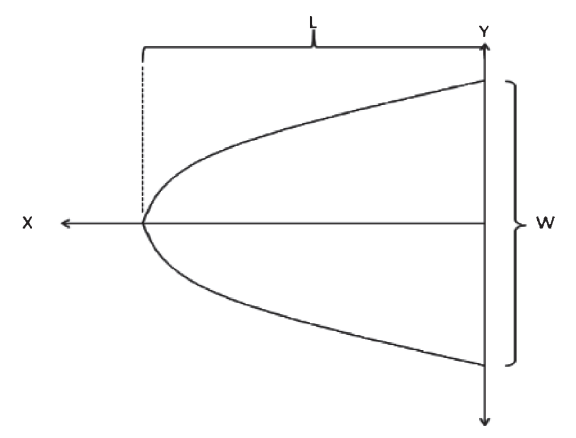

(b) Top view of waverider in XY-plane

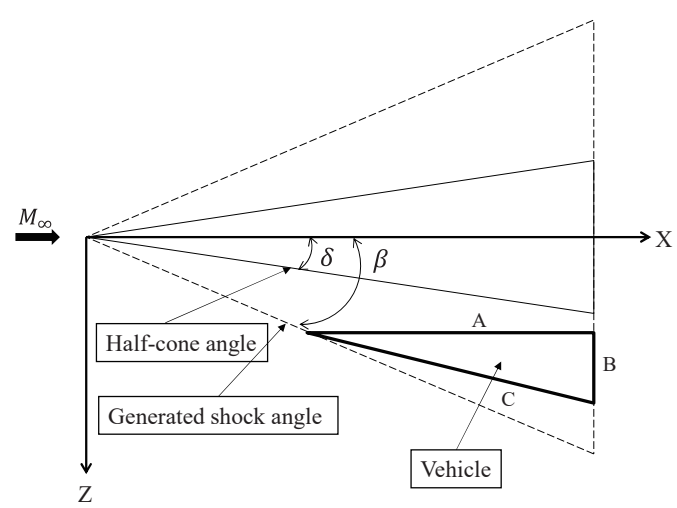

(c) Side view of waverider in XZ-plane

Fig. 2. The waverider freestream surface in A was generated parallel to the streamline. Then, the base plane in B was formed by projecting all of the points from the leading-edge backward. Finally, the compression surface in $\mathrm{C}$ was constructed by the intersection of the freestream trailing-edge and the lower trailing-edge. 
Table 1. Design parameters of cone-derived waverider.

\begin{tabular}{ll}
\hline \multicolumn{1}{c}{ Parameters } & \multicolumn{1}{c}{ Value } \\
\hline Dihedral angle $(\phi)$ & $45,55,65$ \\
Half-cone angle $(\delta)$ & $5,10,15$ \\
Radial distance $\left(R_{0}\right)$ & $0.3,0.5,0.7$ \\
\hline
\end{tabular}

$$
\frac{\beta}{\delta}=\left(\frac{\gamma+1}{2}+\frac{1}{M_{\infty}^{2} \delta^{2}}\right)^{\frac{1}{2}}
$$

The curvature of the base plane is described by:

$$
z=R_{0}+A y^{2}
$$

The freestream surface was aligned to the freestream, and the freestream trailing-edge described a parabola shape as per Eq. (2). The compression surface is formed by the intersection line between the freestream trailing-edge, freestream surface and base plane.

In this study, various cone-derived waveriders were studied in a supersonic flow to observe the sonic boom strength and aerodynamic performance of each design parameter. Twenty-seven waverider models with different design parameters were constructed to conduct the parametric study. The parameters from Table 1 were arranged according to a full-factorial design, with dihedral angles $(\phi)$ of $45^{\circ}, 55^{\circ}$, and $65^{\circ}$, the distance from the center of the cone shock to the freestream surface with respect to the body length $\left(R_{0}\right)$ of $0.3,0.5$, and 0.7 , and half-cone angles $(\delta)$ of $5^{\circ}, 10^{\circ}$, and $15^{\circ}$. The ranges of the shape parameters were determined by the feasibility of the physical shape. For example, the half-cone angle cannot be set to less than $5^{\circ}$ in order to avoid the overlapping between upper and lower surfaces of the waverider.

\subsection{Power-law wedge waverider}

In the research conducted on power-law waveriders, ${ }^{11,12)}$ a model was derived from two-dimensional wedge flow equations that define the curvature of the upper-surface and the planform. The planform shape is similar to that of Nonweiler's caret wings. However, it has been proven to be more flexible. This method gives a wedge-shaped side profile and parabolic-shaped trailing-edge, as shown in Fig. 3. The planform and upper-surface curvature were parameterized using Eqs. (3) and (4), respectively, where $A, B$, and $n$ are the power-law scaling parameters. The planform and upper-surface were described as

$$
Y_{p}=A x^{n}
$$

and

$$
Y_{u}=B\left(z_{u}\right)^{n}
$$

where the lower surface is defined using Eq. (5) to ensure a constant wedge angle on a planar shock, and where $\theta$ represents the assumed wedge angle.
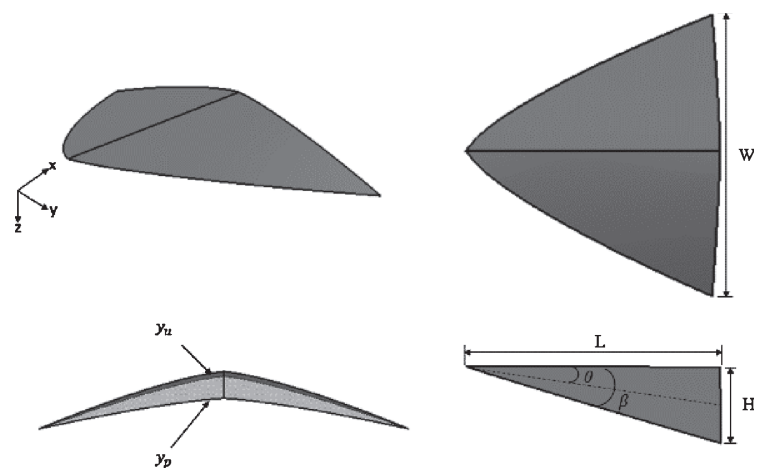

Fig. 3. Geometry definition of power-law waverider.

Table 2. Design parameters of the power-law waverider.

\begin{tabular}{ll}
\hline \multicolumn{1}{c}{ Parameters } & Value \\
\hline Wedge angle $(\theta)$ & $5,7,9$ \\
Power-law component $(n)$ & $0.5,0.6,0.7$ \\
\hline
\end{tabular}

$$
\begin{gathered}
\tan \theta=\frac{z_{L}-\left(\frac{y_{u}}{y_{p}}\right)^{1 / n}}{x-\left(\frac{y_{p}}{A}\right)^{1 / n}} \\
B=\frac{A}{\tan ^{n} \beta} \\
H=\left(\frac{A}{B}\right)^{1 / n} L=L \tan \beta \\
W=2 A L^{n}
\end{gathered}
$$

In general, a waverider is designed to ensure the attachment of the shock-wave surface with angle $\beta$ at the leadingedge, which was determined using Eq. (6). This simplicity also allowed geometric values to be prescribed by the vehicle height $H$ and width $W$, as given by Eqs. (7) and (8), respectively.

The geometry was designed with the same length and flow conditions as a cone-derived waverider. The design parameters $\theta$ and $n$ were chosen for parametric study as described in Table 2. The upper and lower bounds of the shape parameters are determined using the same method as the conederived waverider and set as the shape parameters. The shape parameters of the power-law waverider design parameters are chosen by varying either the number of $n$ or wedge angle, and the other parameter is kept fixed. For this study, $\theta$ is fixed to 7 when observing parameter $n(0.5,0.6,0.7)$, and $n$ is fixed to 0.7 when observing $\theta(5,7,9)$.

\subsection{Osculating-cone waverider}

A more flexible methodology for designing a waverider vehicle was introduced by Lewis and Takashima, 1996. ${ }^{13)}$ The method does not require an existing body to generate a conical flow field. Instead, a local conical flow is defined in the slice osculating plane. This methodology is able to de- 


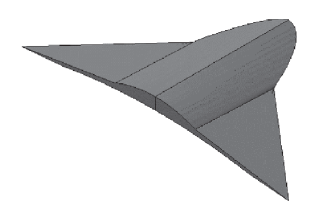

(a) Waverider geometry in perspective

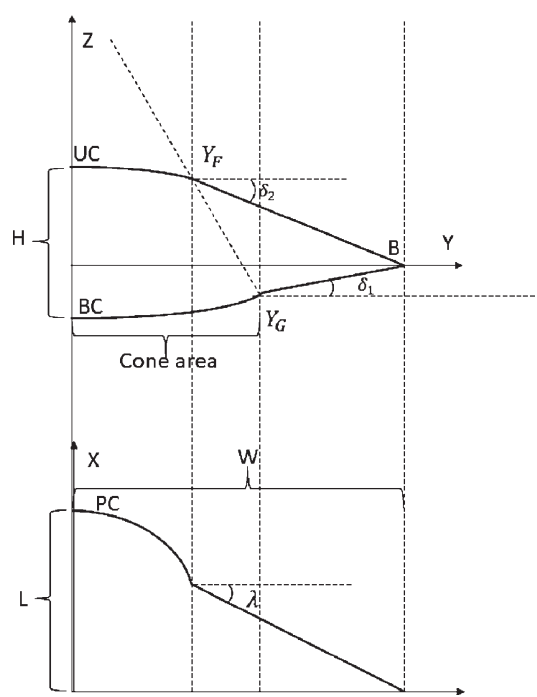

(b) Geometric relationship

Fig. 4. Geometry definition of an osculating-cone waverider. The geometric parameters were defined to build a conical section in the center of the vehicle, and the swept wing is shaped in the area outside of the body.

termine the desired shock instead of the body of the shock generator, which has great potential for expanding the design space. Later, Lewis and Takashima used the osculating-cone method to design a forebody hypersonic vehicle by specifying the center body as a wedge flow field. In this study, the local-cone shock was created to fit the specific location of the center body where the outside section creates a combination of two-dimensional wedge flow and swept wings.

This study modified the osculating-cone waverider at the planform and lower surface. The geometric relationship allows the waverider to specify the desired sweep $\lambda$ and determine the location of the conical shock surface, as shown in Fig. 4(b). The waverider was dissected into a cone-wedge combination by specifying a conical body at the center section and a wedge in the wing area.

$$
\begin{gathered}
U C^{\prime}\left(Y_{G}\right)=\tan \delta_{1} \\
B C^{\prime}\left(Y_{F}\right)=\tan \delta_{2} \\
P C^{\prime}\left(Y_{F}\right)=\tan \lambda \\
\frac{\cos \delta_{2}}{\sin \left(\delta_{1}-\delta_{2}\right)}=\frac{1}{\tan \lambda \tan \beta} \\
\frac{U C\left(Y_{F}\right)-B C\left(Y_{G}\right)}{Y_{F}-Y_{G}}=-\frac{1}{B C^{\prime}\left(Y_{G}\right)}
\end{gathered}
$$

The set of Eqs. (9)-(11), and (13) were used to solve the geometric relationship of the upper-surface curve (UC), lower-
Table 3. Design parameters for osculating-cone waveriders.

\begin{tabular}{ll}
\hline \multicolumn{1}{c}{ Parameters } & Value \\
\hline Shock angle $(\beta)$ & 5,10 \\
Dihedral angle $\left(\delta_{1}\right)$ & $-5,5$ \\
Local sweep $\lambda$ & 40,50 \\
$Y_{G}$ & $0.3,0.7$ \\
$Y_{F}$ & $0.3,0.7$ \\
\hline
\end{tabular}

surface curve (BC), and planform curve (PC) with respect to the location of the local sweep. The dihedral angles were obtained by deriving points $Y_{F}, Y_{G}$ (location of sweep angle on the upper and lower surfaces in respect to the ratio of body length) and their relationship in Eq. (12). A parametric study of the osculating-cone waverider was conducted using five design parameters, as detailed in Table 3 . The shape parameters of osculating-cone waverider are determined for both the upper and lower ranges. The number of designs are generated according to full factorial design.

\section{Numerical Simulation Methods}

\subsection{Computational fluid dynamics}

The parametric study used the computational fluid dynamic (CFD) approach to obtain the aerodynamics of the waverider. A three-dimensional unstructured mesh of the flow domain was created using the unstructured grid generator software MEGG3D. ${ }^{14-16)}$

An unstructured collar mesh is created around the vehicle. The grid spacing at the core is approximately set to between 0.001 to 0.007 , and normalized by the body length. The grid spacing gradually increases as it is located farther from the core to reduce the CFD cost. Grid convergence has been checked to select the mesh quality balancing the resolution and computational time. The mesh is visualized in Fig. 5. The flow solver Tohoku University Aerodynamic Simulation (TAS) code employed Euler equations for the problems. The equations were numerically solved using the cell-vertex finite volume scheme. Numerical inviscid flux was computed using the approximate Riemann solver of Harten-Lax-van Leer-Einfeldt-Wada (HLLEW), ${ }^{17}$ ) in which second-order spatial accuracy was realized through linear reconstruction of the primitive flow variables with Venkatakrishnan's limiter. ${ }^{18)}$ The lower/upper symmetric Gauss-Seidel (LUSGS) implicit method ${ }^{19)}$ was used for time integration. Table 4 explains the CFD settings of the TAS code.

\subsection{Sonic boom propagation}

To calculate the sonic boom strength, near-field overpressure was extracted from the numerical results at a location below the vehicle, equivalent to 1.2 body-lengths. Xnoise, a sonic boom analysis tool based on the augmented Burgers equations, ${ }^{20,21)}$ was used to calculate the far-field overpressure generated by a waverider at Mach 1.5 . The vehicle was 50-m long. The reflection coefficient at the ground was set to 1.9. In the sonic boom calculations, the governing equations are described as follows: 


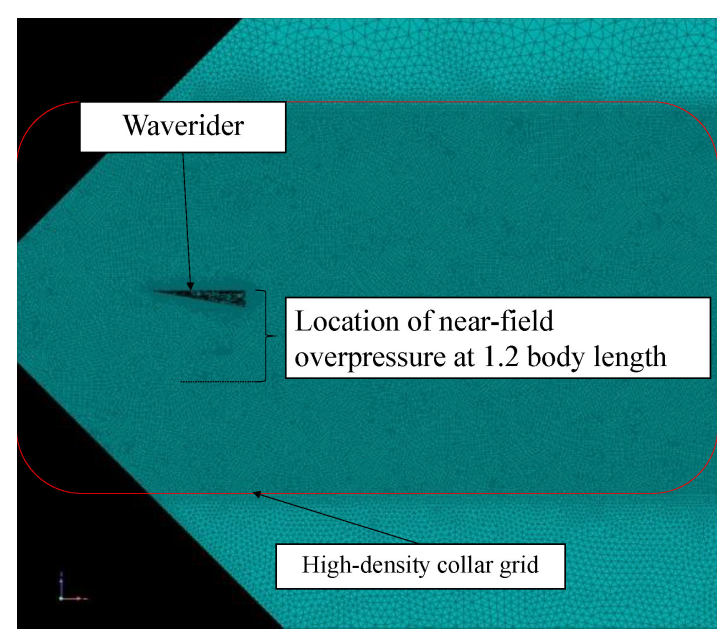

Fig. 5. An example of at unstructured core mesh (Y-plane).

Table 4. TAS code settings.

\begin{tabular}{ll}
\hline Calculation condition & \multicolumn{1}{c}{ Settings } \\
\hline Governing equations & Euler inviscid \\
Discretization & Finite volume cell-vertex \\
Convection flux & HLLEW approximate Riemann \\
Time integration & LU-SGS implicit \\
\hline
\end{tabular}

$$
\begin{gathered}
\frac{\partial p}{\partial x}=\frac{\beta}{2 \rho_{0} c_{0}^{3}} \frac{\partial p^{2}}{\partial t^{\prime}}-\frac{1}{2 A} \frac{\partial A}{\partial x} p+\frac{1}{2 \rho_{0} c_{0}} \frac{\partial\left(\rho_{0} c_{0}\right)}{\partial x} p \\
+\frac{\delta}{2 c_{0}^{3}} \frac{\partial^{2} p}{\partial t^{\prime 2}}+\sum_{i} \frac{(\Delta c)_{i} \tau_{i}}{c_{0}^{2}}\left(1+\tau_{i} \frac{\partial}{\partial t^{\prime}}\right)^{-1} \frac{\partial^{2} p}{\partial t^{\prime 2}} \\
\frac{\partial p}{\partial x}=\frac{\beta}{2 \rho_{0} c_{0}^{3}} \frac{\partial p^{2}}{\partial t^{\prime}} \\
\frac{\partial p}{\partial x}=-\frac{1}{2 A} \frac{\partial A}{\partial x} p \\
\frac{\partial p}{2 \rho_{0} c_{0}} \frac{\partial\left(\rho_{0} c_{0}\right)}{\partial x} p \\
\frac{\partial p}{\partial x}=\frac{\delta}{2 c_{0}^{3}} \frac{\partial^{2} p}{\partial t^{\prime 2}} \\
c_{0}^{2}\left(1+\tau_{i} \frac{\partial}{\partial t^{\prime}}\right)^{-1} \frac{\partial^{2} p}{\partial t^{\prime 2}}, \quad i=1,2, \cdots
\end{gathered}
$$

where $p$ is the pressure, $x$ is the distance, $A$ is the raytube area, $t^{\prime}$ is the delay time, $c_{0}$ is the sound velocity, $\rho_{0}$ is the density, $\beta$ is the nonlinear coefficient, $\delta$ is the diffusion rate, $\tau_{i}$ is the relaxation time, and $\Delta c$ is the increment of sound velocity. Equation (14) was split into Eqs. (15)-(19) using an operator splitting method, giving terms for nonlinearity, geometrical spreading, atmospheric stratification, thermoviscous absorption, and the effects of a finite number of individual relaxation processes $i$. Equations (15)-(19) were solved separately for each time step, evaluated, and then the nonlinear term was integrated.

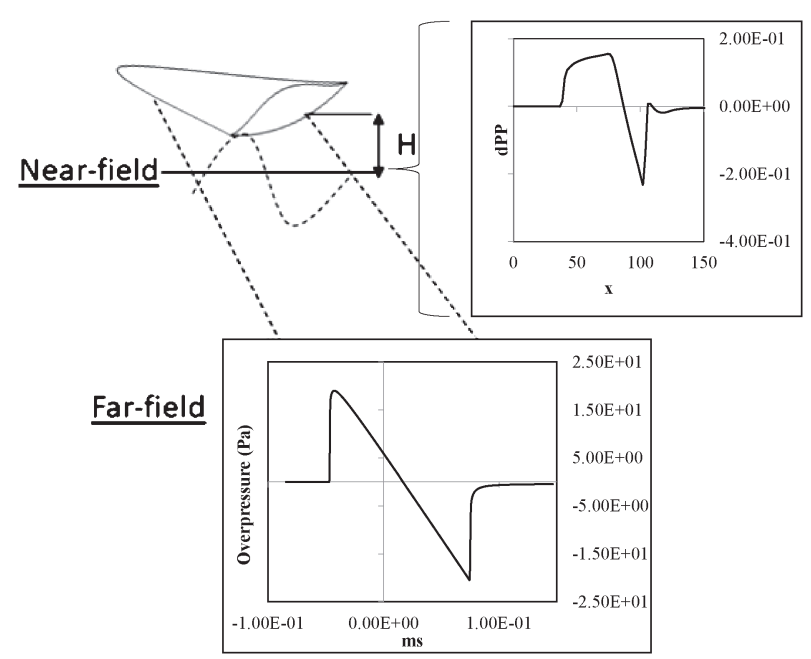

Fig. 6. Sonic boom propagation under the vehicle.

From Fig. 6, the near-field signature is captured below the aircraft under-surface to calculate far-field overpressure using Xnoise. For this study, a strong shock appears in the front, creating a sharp rise time to the $\mathrm{N}$-wave signature. Moreover, a simple $\mathrm{N}$-wave pressure signature appears in every geometry because the other parts that can change the signature (e.g., stabilizer) are not integrated to the waverider.

\section{Results and Discussion}

The geometric parameters of waveriders at a designed Mach number of 1.5 are discussed in this section. The reference shape in this study is determined by width-to-length ratio equal to $2: 1$. The reference area of the waverider is taken from the projected planform area. Each design parameter range is obtained by finding the geometric feasibility of the physical geometry. The results demonstrate the trend of aerodynamics and the specific configuration of the waveriders. The outcome of the sonic-boom evaluation is represented by $P_{-}$fop (far-field overpressure).

\subsection{Cone-derived waverider}

The design parameters of a cone-derived waverider create a different geometry, as shown in Fig. 7. The dihedral angle is varied in the curvature of the wingspan, and increasing the dihedral angle changes the vehicle shape to be convex. At the designed Mach number 1.5, the range of the design parameters should stay between $45^{\circ}$ and $65^{\circ}$. If the angle is outside this range, it will either create an extremely curved wingspan or completely flat wing with a self-intersection of the top and lower surfaces. Moreover, the extreme pointy wing tips can cause surface overlapping between the base plane, uppersurface and under-surface at the end of the tips. Therefore, the pointy tips are truncated to resolve this issue.

The half-cone angle primarily influenced the thickness and was responsible for tailoring the shock surface of the vehicle body. As the angle increased, the body of the waverider became thicker, increasing the volume of the center body section. Suitable values of the half-cone angle in this study ranged from $5^{\circ}$ to $15^{\circ}$. 


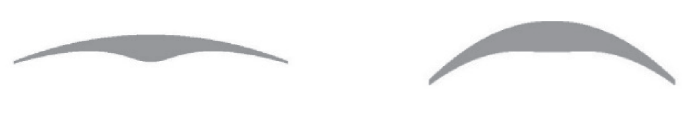

(a) Dihedral angle

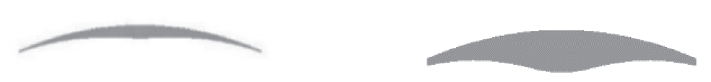

(b) Half-cone angle
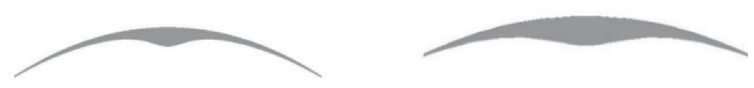

(c) $R_{0}$ distance

Fig. 7. Rear view of cone-derived waveriders shows different variations from driven by three design parameters.

The prescribed length to determine the freestream trailingedge $\left(R_{0}\right)$ was the parameter that determined the freestream surface. Therefore, the $R_{0}$ effect on the curvature of the freestream surface directly influenced the slenderness and narrowed the upper-surface. As the value of $R_{0}$ increased, the vehicle body and wingspan became thinner.

From the parameter trends shown in Fig. 8, increasing the half-cone angle $(\delta)$ will increase $C_{L}, C_{D}$, and far-field overpressure $\left(P_{-}\right.$fop $)$as $L / D$ decreases. However, when the dihedral angle $(\phi)$ increased, all objectives behaved inversely proportional, and $P_{-}$fop decreased as $L / D$ increased. Regarding $R_{0}$, this parameter showed less significant influence on the aerodynamics, but some geometries with low $R_{0}$ values indicated low overpressures.

As shown in Fig. 9, a waverider model, Cone6553 ( $\phi=65, \delta=5, R_{0}=3$, resulted in a lower overpressure than the other models. The high overpressure area concentrated along the tips of the leading-edge and was evenly distributed outside the center section owing to the small bump. The sharp leading-edge and the small frontal area also helped to reduce the large amount of drag. However, the lift generated by this model was relatively low owing to the small area of the shock-capturing surface.

\subsection{Power-law body waverider}

Two main design parameters that showed a significant impact on the shape of the power-law body waverider were compared under the same flow conditions as the conederived waverider. The highly flexible planform configuration had an advantage over the generic cone-derived waverider. The power-law waverider was designed with a fixed dimension of $W / L=2$. The power-law component, $n$, showed the greatest contribution to the planform layout. As can be seen in the top view of Fig. 10, a small $n$ resulted in a sharp vehicle nose and a caret wing-shape planform.

A sharply bent bottom surface with a caret wing planform tends to provide better lift owing to the highly concentrated pressure along the leading-edge, as shown in Fig. 11. However, the overpressure ground signature was higher because of the stronger shock wave being trapped under the compression surface. As can be seen in Table 5, a larger $n$ produced

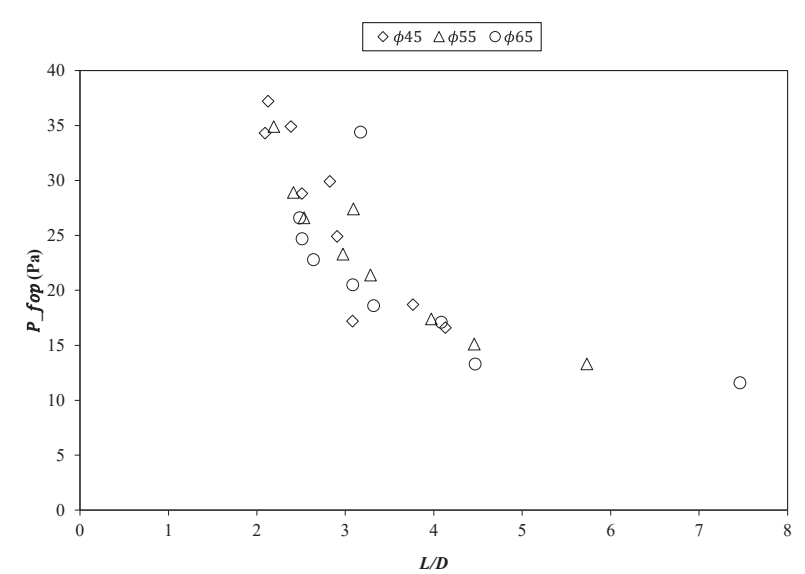

(a) Dihedral angle

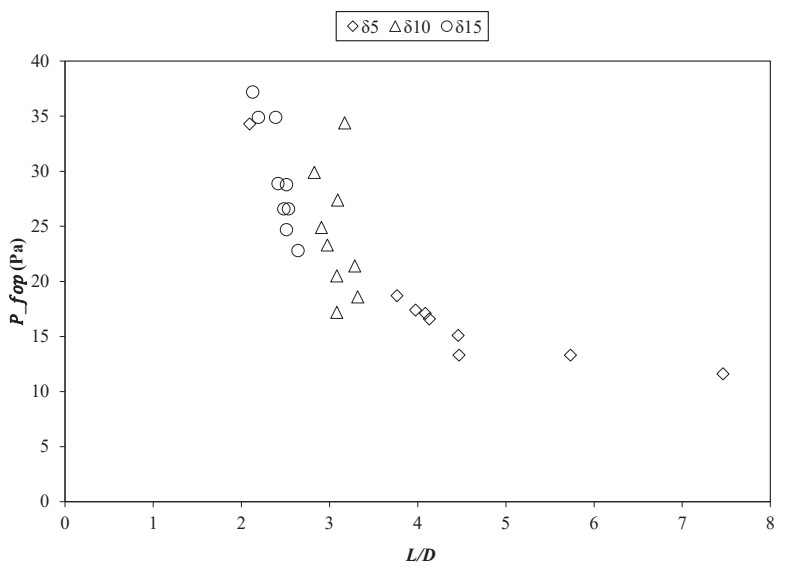

(b) Cone angle

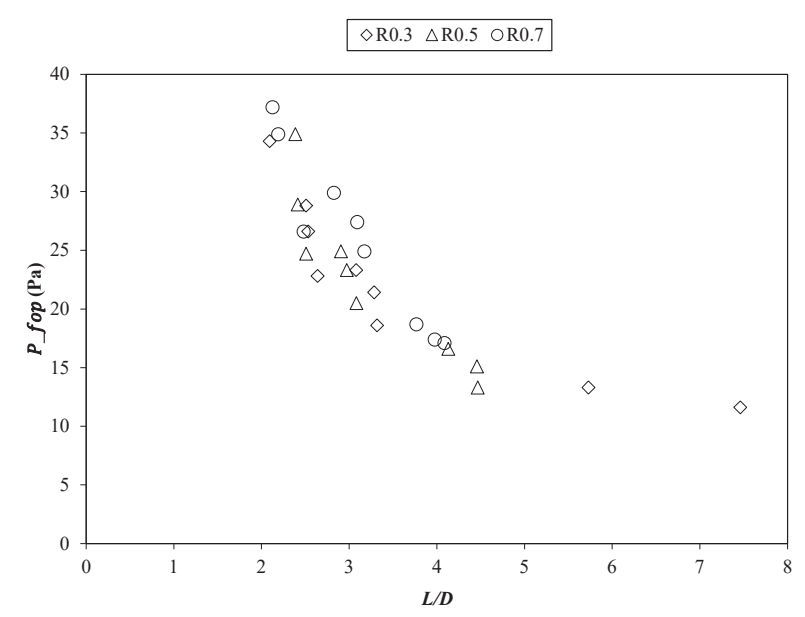

(c) $R_{0}$

Fig. 8. Three design parameter trends of a cone-derived waverider corresponding to overpressure and lift-to-drag ratio.

an even pressure distribution and lower overpressure concentrations along the leading-edge.

The center thickness of the power-law waverider was mainly described by the wedge angle. A high angle resulted in the vehicle having greater volume. According to Fig. 12, vehicle thickness had the most considerable contribution to the ground signature overpressure, as the large volume generated significantly strong shocks along the bottom surface. A large wedge angle also generated high lift and drag simultaneously, as shown in Table 6. However, the drawback was 

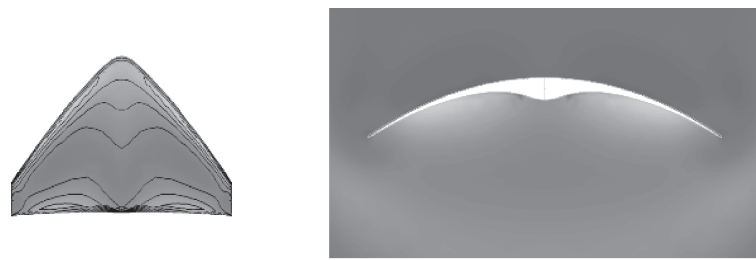

Overpressure (Pa)

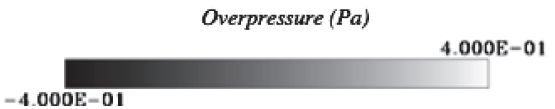

Fig. 9. Model Cone6553 $\left(\phi=65, \delta=5, R_{0}=3, P_{-}\right.$fop $=11.60 \mathrm{~Pa}$, $\left.C_{L}=0.0895, C_{D}=0.0119, L / D=7.46\right)$ produces the lowest overpressure. The small bump appears in the center section of the vehicle.

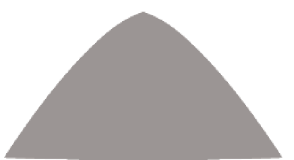

(a) $n=0.7$

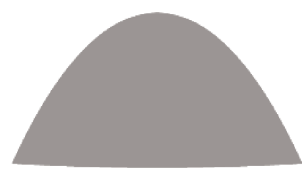

(b) $n=0.5$
Fig. 10. The planform of a power-law waverider defines the shape using the power-law component.

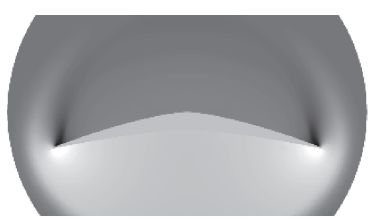

(a) $n=0.7$

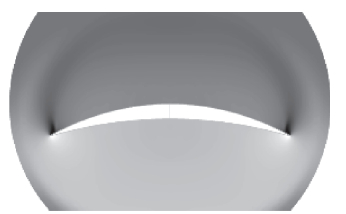

(b) $n=0.5$
Overpressure $(\mathrm{Pa})$

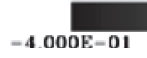

.000E-01

Fig. 11. Overpressure influenced by the power-law component.

Table 5. The power-law component.

\begin{tabular}{cccc}
\hline$n$ & $P_{-}$fop $(\mathrm{Pa})$ & $C_{L}$ & $C_{D}$ \\
\hline 0.5 & 86.51 & 0.2298 & 0.0733 \\
0.6 & 63.39 & 0.2186 & 0.0651 \\
0.7 & 63.71 & 0.2068 & 0.0610 \\
\hline
\end{tabular}

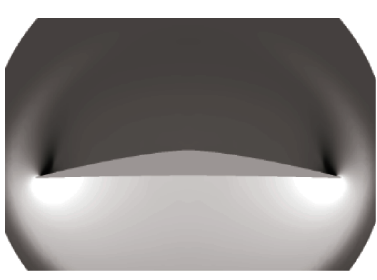

(a) $\theta=9$

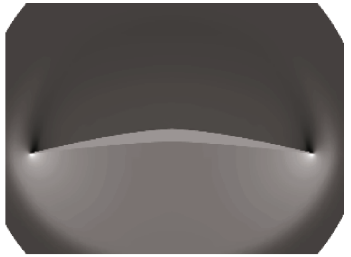

(b) $\theta=5$

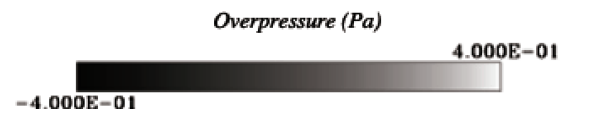

Fig. 12. Overpressure influenced by wedge angle.

a lower $L / D$ when compared to smaller wedge angles. When compared with a cone-derived waverider, the cone-derived waverider having the same span and length had lower overpressure and higher $L / D$, in addition efficient volume in the
Table 6. The wedge angle.

\begin{tabular}{cccc}
\hline$\theta$ & $P_{-}$fop $(\mathrm{Pa})$ & $C_{L}$ & $C_{D}$ \\
\hline 5 & 26.2764 & 0.1475 & 0.0392 \\
7 & 82.5925 & 0.2043 & 0.0607 \\
9 & 71.0136 & 0.2595 & 0.0902 \\
\hline
\end{tabular}

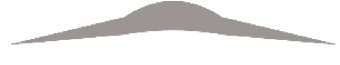

(a) Conical shock $10^{\circ}$

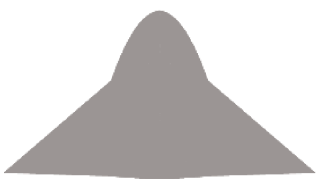

(c) Local swept angle $40^{\circ}$

(e) Positive dihedral (b) Conical shock $5^{\circ}$

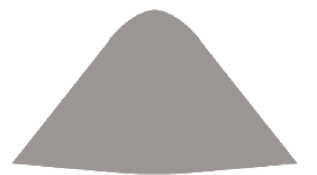

(d) Local swept angle $50^{\circ}$

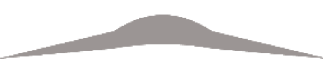

(f) Negative dihedral

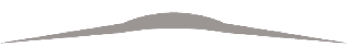

Fig. 13. Conical shock angle, swept angle, and dihedral angle.

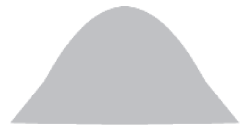

(a) $Y_{G}=0.3, Y_{F}=0.7$, Top-view

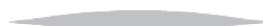

(c) $Y_{G}=0.3, Y_{F}=0.7$, Back-view

(d) $Y_{G}=0.7, Y_{F}=0.3$, Back-view
Fig. 14. $Y_{G}$ and $Y_{F}$ determine the shock-wave location in the front and back areas.

center section. However, the design space of the power-law configuration was more substantial than the generic conetype because the planform could be freely configured using polynomial relations.

\subsection{Osculating-cone waverider}

A combination of the cone-derived and power-law waveriders was applied in the osculating-cone waverider method. As shown in Figs. 13 and 14, the conical section was defined by parameter $\beta$, controlling the volume and center-line body of the vehicle. $Y_{F}$ and $Y_{G}$ start separating the conical body to create local swept and dihedral angles.

As seen in Fig. 14, the combination of $Y_{G}$ and $Y_{F}$ tended to result in various distributions of ground signature and aerodynamics because the shock-capturing surface changed depending on the position of the parameters. However, the majority of $Y_{G}=0.7$ and $Y_{F}=0.3$ tended to produce lower overpressure designs. Negative dihedral and smaller values for the local swept angle also contributed to lower overpressure.

The most dominant parameter was the conical shock angle, which defined the center section. A higher angle provided a thicker vehicle body that increased the strength of the overpressure. Meanwhile, the frontal surface area was strongly affected by the drag coefficient.

$Y_{G}$ and $Y_{F}$ were the parameters that controlled the conical part and shock-wave capturing surface, respectively. The ex- 


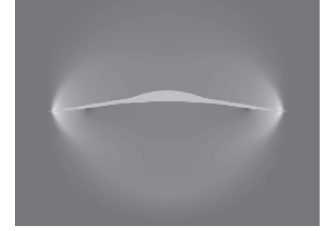

(a) OSC12 base plane

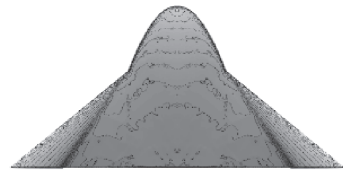

(b) Overpressure contour

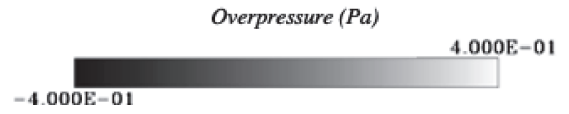

Fig. 15. Model OSC12 $\left(\beta=5, \delta_{1}=-5, Y_{G}=0.7, Y_{F}=0.3, \lambda=40\right)$.

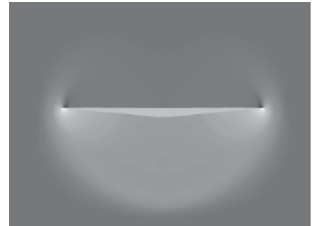

(a) OSC30 base plane

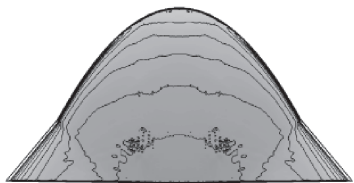

(b) Overpressure contour

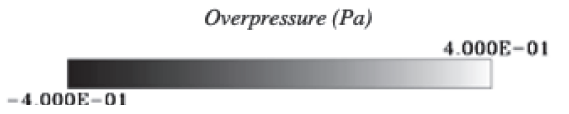

Fig. 16. Model OSC30 $\left(\beta=5, \delta_{1}=5, Y_{G}=0.3, Y_{F}=0.7, \lambda=50\right)$.

tended area of the conical body helped increase the volume, and wide shock-capturing surfaces can provide a large amount of lift. However, both have drawbacks from significantly increased drag and overpressure.

Comparing Figs. 15 and 16, the small shock capturing surface in the front (OSC12) produced a significantly lower farfield overpressure, $26.441 \mathrm{~Pa}$, than the model with a more significant shock-capturing surface in the front (OSC30), 51.339 Pa. The overpressure distribution from OSC12 was more even due to the greater sweep area. Conversely, the aerodynamic performance of OSC30 gave a $L / D=3.241$, which was significantly greater than that of OSC12, $L / D=0.357$. The lift generated from the frontal shockcapturing area of the waverider indicated a significant improvement in the aerodynamic performance of the waverider.

The parameter trend according to each objective is represented by self-organizing map (SOM) plot in Fig. 17. The SOM shows the relationship between the design of each parameter and objectives by creating group clusters of interested objective. The overpressure and $L / D$ geometries were dominated by the shock angle and dihedral angle. Decreasing $\beta$ and $\delta_{1}$ lowered $L / D$ and overpressure. From the plot, the maximum $L / D$ and overpressure were located in different areas. Therefore, the combination of a local swept, $Y_{G}$ and $Y_{F}$, also increased the complexity of the objective space. Moreover, the plot shows that the high $L / D$ designs and low-boom designs are competing because the cluster of the low overpressure geometries is located in low $L / D$ cluster.

The design knowledge for waverider obtained through the present parametric study is further expanded towards the fair comparisons. The low-boom design for each type of waverider is selected to compare with a conventional delta-wing.
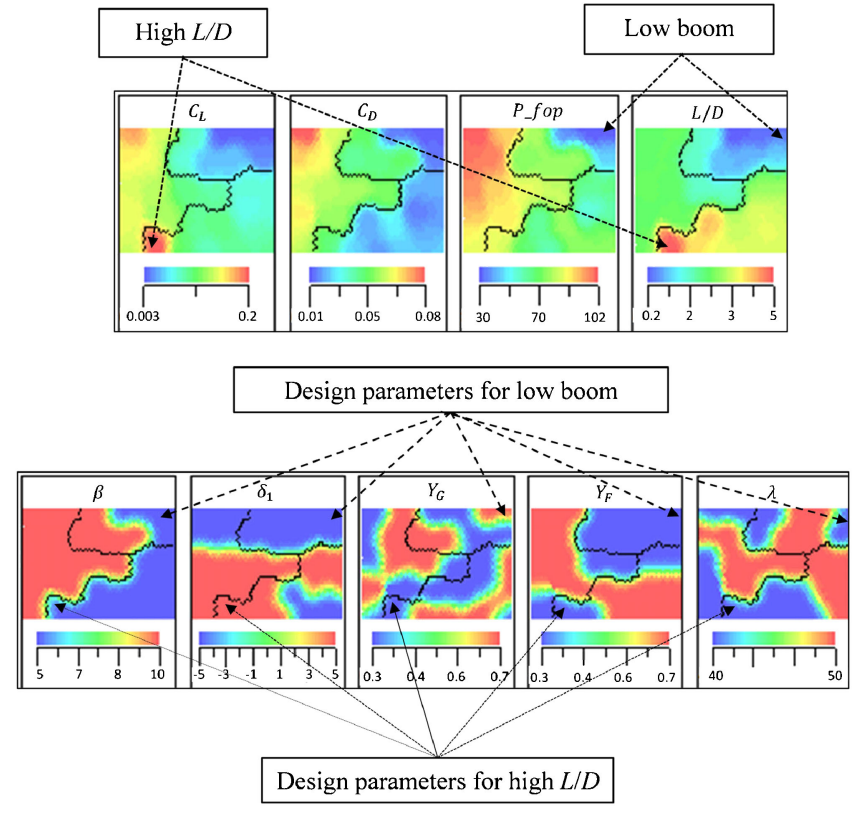

Fig. 17. Parameters trend of osculating-cone waverider corresponding to aerodynamics and overpressure.

All of the waveriders have the same object/shock angle $\left(5^{\circ}\right)$ and same width-to-length ratio (2:1). In this comparison, the models Cone6553 $\left(\phi=65, \delta=5, R_{0}=3\right), \quad$ pwt5-n7 $(\theta=5, n=0.7)$ and $\operatorname{OSC1} 2\left(\beta=5, \delta_{1}=-5, Y_{G}=0.7\right.$, $\left.Y_{F}=0.3, \lambda=40\right)$ are varied at different angles of attack $\left(0^{\circ}, 2^{\circ}, 4^{\circ}\right.$ and $\left.6^{\circ}\right)$. A wedge delta-wing with the same body thickness as other waverider geometries was also compared.

From Fig. 18(a), the results of $L / D$ at different angles of attack show that all types of waveriders yield a better $L / D$ than the wedge delta-wing under the same lift conditions. This is because the compression surface of the waverider utilizes the shock wave to produce compression lift from the under surface of the aircraft. In this research, $L / D$ of the cone-derived waverider and power-law waverider decline at higher angles-of-attack due to greater drag. On the other hand, the osculating-cone waverider can potentially maintain a higher $L / D$ as the angle-of-attack increases. The powerlaw waverider and the osculating-cone waverider obtain greater far-field overpressure than the delta-wing. The cone-derived waverider shows less overpressure compared to the delta-wing under lower lift conditions because the small bump on the bottom surface weakens the overpressure at the center section of the aircraft. As the angle-of-attack increases, flow separation at the base plane of the waverider becomes a significant issue because it increases overpressure and drag. In this comparison, viscous drag is not included in the Euler analysis. Therefore, the $L / D$ is expected to be a smaller number if the skin friction drag is taken into account. The viscous component may also change the $L / D$ of the waverider due to the size of the separation at the rear base and leading-edge of the waverider. In this study, the viscosity is neglected when considering the compression lift of a supersonic waverider under the design conditions of a lowsupersonic Mach number and small angle-of-attack. 


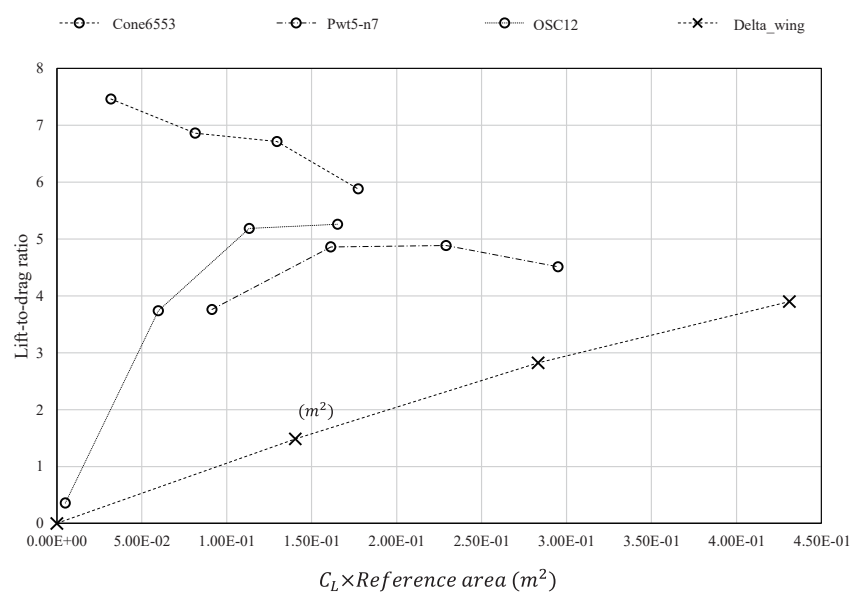

(a) $L / D$ vs $C_{L} \times$ Reference area

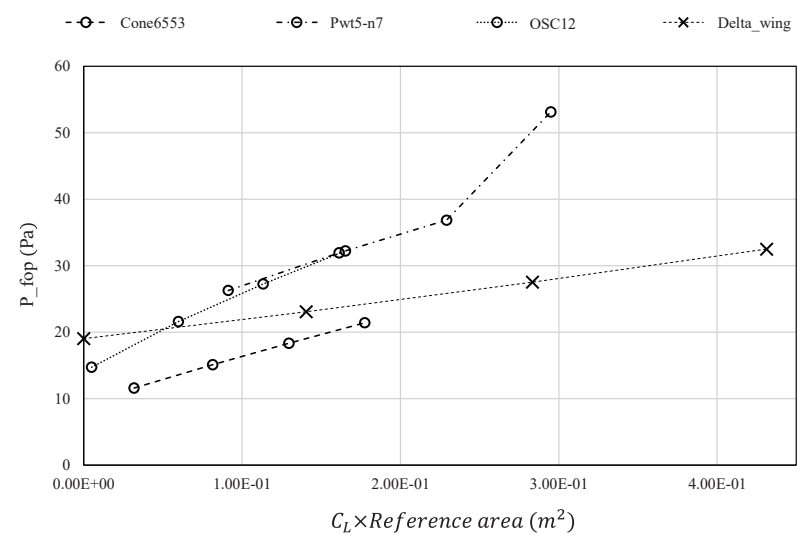

(b) Overpressure vs $C_{L} \times$ Reference area

Fig. 18. Comparison of $L / D$ and overpressure between waveriders and wedge delta-wing under the same lift conditions $\left(C_{L} \times\right.$ Reference area $)$.

\section{Conclusion}

This research proposed waverider methods for solving supersonic aircraft problems, namely sonic boom and aerodynamic performance. A parametric study was performed by applying numerical simulation using an Euler-based inviscid flow solver. Twenty-seven cases of cone-derived waverider geometries with variations in three design parameters were analyzed under a freestream condition of Mach 1.5 at an altitude of $18,000 \mathrm{~m}$, and angle-of-attack of $0^{\circ}$. A shock wave with an $\mathrm{N}$-shaped signature was extracted from the overpressure in the near-field and assigned as input for measuring the ground signature. The three design parameters have a significant impact on overpressure mitigation and $L / D$. Small half-cone angle values had the most significant impact in terms of the minimum far-field overpressure. When the dihedral angle increased, the overpressure decreased slightly, and the decrease in overpressure was inversely proportional to $R_{0} . R_{0}$ showed the least impact on both the aerodynamics and overpressure. However, it appeared that a high dihedral and a low $R_{0}$ tended to provide lower drag and lower overpressure. The half-cone angle design parameter mainly affected the center section volume size and amount of drag on the vehicle. The design space of the generic cone-derived waverider was relatively small when compared to other types.

The power-law waverider provided greater flexibility in the design space compared to the cone-derived waveriderthe planform configuration, which was freely determined by the power-law component. This parameter had a high impact, particularly on the aerodynamics, as the frontal area significantly affected the drag coefficient. The various planform shapes depended on the value of the power-law component, where a predefined wedge angle determined the volume and shock-wave surface, causing a major change in $C_{L}, C_{D}$ and overpressure. However, a major tradeoff of this configuration was the lack of volumetric efficiency and space in the center section. The osculating-cone waverider was applied to obtain the merits from both the cone-derived (volume and lowboom) waverider and power-law waverider (flexibility). Thirty-two cases were studied to find the trends of five design parameters. The coordination of $Y_{G}$ and $Y_{F}$ controlled the conical body width, shock-capturing surface, and local swept-angle position. The conical shock angle determined the volume, which corresponded to the overpressure strength. The local swept-angle and dihedral angle helped control planform, which contributed to aerodynamics. Among the three types, the osculating-cone waverider with local swept-wing control showed the highest flexibility in the design space of all the waveriders. Controlling of the shock-capturing section of the frontal area and sweep angle can produce significant improvements in aerodynamics and ground signature mitigation.

For the supersonic waverider, the detached shock wave occasionally appears in both cone-derived and power-law waveriders because the flow is subsonic around the leading-edge. The detached shock wave at the leading-edge causes pressure leaking upward and generates less $L / D$ in low supersonic conditions. However, the compression surface of the waverider still provides good aerodynamic performance compared to the conventional delta-wing. A new finding we obtain during supersonic waverider research is that compression lift can still be obtained at low-supersonic speed. The supersonic waverider can operate at a low angleof-attack and yield greater $L / D$ than the generic wedge delta-wing. In addition, the low-boom and high $L / D$ designs of the osculating-cone waverider are in a trade-off relationship. Therefore, increasing compression lift also increases far-field overpressure. The waverider can mitigate its sonic boom by minimizing its shock angle. On the other hand, the payload volume is also reduced because it is affected by the designed shock angle. This is a new challenge that requires multi-objective optimization to explore and exploit the set of solutions for a specific mission. Accordingly, design exploration is subject of future research.

\section{Acknowledgments}

Numerical simulations were performed on the supercomputer system "AFI-NITY" at the Advanced Fluid Information Research Center, Institute of Fluid Science, Tohoku University. 


\section{References}

1) Sun, Y. and Smith, H.: Review and Prospect of Supersonic Business Jet Design, Prog. Aerosp. Sci., 90 (2017), pp. 12-38.

2) Tang, Y. R., Luther, L., Elias, B., and Morgan, D.: Supersonic Passenger Flight, Congressional Research Service, 2018.

3) Smith, H.: A Review of Supersonic Business Jet Design Issues, Aeronaut. J., 111 (2007), pp. 761-776.

4) Choi, S., Alonso, J. J., and Kroo, M. I.: Multi-Fidelity Design Optimization of Low-Boom Supersonic Business Jets, 10th AIAA/ISSMO Multidisciplinary Analysis and Optimization Conference, 2004.

5) Gan, J. and Zha, G.: Analysis of a Low Boom Supersonic Flying Wing Preliminary Design, 53rd AIAA Aerospace Science Meeting, 2015.

6) Pawlowski, W. J., Graham, H. D., and Baccadoro, H. C.: Origins and Overview of the Shaped Sonic Boom Demonstration Program, 43rd AIAA Aerospace Sciences Meeting and Exhibit, 2005.

7) Rasmussen, M. L. and He, X.: Analysis of Cone-Derived Waverider by Hypersonic Small-Disturbance Theory, Proc. of 1st International Hypersonic Waverider Symposium, 1990.

8) He, X. and Rasmussen, M. L.: Computational Analysis of Off-Design Waveriders, J. Aircraft, 31 (1994), pp. 345-353.

9) Rasmussen, M. L.: Waverider Configurations Derived from Inclined Circuler and Elliptic Cones, J. Spacecr. Rockets, 17 (1980), pp. 537-545.

10) Anderson, J. D., Jr., Lewis, M. J., and Corda, S.: Several Families of Viscous Optimized Waveriders: A Review of Waverider Research at the University of Maryland, Proc. of 1st International Hypersonic Waverider Symposium, 1990.

11) Rasmussen, M. and Brandes-Dunkam, B.: Hypersonic Waverider Generated from Power-Law Shock, AIAA 6th International Aerospace Planes and Hypersonics Technologies Conference, 1995.

12) Starkey, P. R.: A Simple Analytical Model for Parametric Studies of
Hypersonic Waveriders, 21st Congress of the International Council of the Aeronautical Sciences, 1998.

13) Takashima, N. and Lewis, M. J.: Engine-airframe Integration on Osculating Cone Waverider-based Vehicle Designs, AIAA Paper 96-2551, 1996.

14) Ito, Y. and Nakahashi, K.: Direct Surface Triangulation Using Stereolithography Data, AIAA J., 40 (2002), pp. 490-496.

15) Ito, Y. and Nakahashi, K.: Unstructured Mesh Generation for Viscous Flow Computations, 11th International Meshing Roundtable, 2002, pp. 367-377.

16) Ito, Y. and Nakahashi, K.: Surface Triangulation for Polygonal Models Based on CAD Data, Int. J. Numer. Meth. Fluids, 39 (2002), pp. 75-96.

17) Obayashi, S. and Guruswamy, G. P.: Convergence Acceleration of an Aeroelastic Navier-Stokes Solver, AIAA J., 33 (1994), pp. 1134-1141.

18) Venkatakrishnan, V.: On the Accuracy of Limiters and Convergence to Steady State Solutions, AIAA Paper 93-0880, 1993.

19) Sharov, D. and Nakahashi, K.: Reordering of Hybrid Unstructured Grids for Lower-Upper Symmetric Gauss-Seidel Computations, AIAA J., 36 (1998), pp. 484-486.

20) Yamamoto, M., Hashimoto, A., Takahashi, T., Kamakura, T., and Sakai, T.: Numerical Simulation for Sonic Boom Propagation through an Inhomogeneous Atmosphere with Winds, AIP Conference Proceeding, 2012.

21) Ishikawa, H., Makino, Y., Ito, T., and Fumitake, K.: Sonic Boom Prediction Using Multi-Block Structured Grids CFD Code Considering Jet-On Effects, Proc. 27th AIAA Applied Aerodynamics Conference, 2009.

Naofumi Ohnishi

Associate Editor 